\title{
The Increasing Of Students' Satisfaction and Loyalty by the Use of Customer Relationship Management (CRM) (A Case Study in Medical Education Institutions, Nursing Study Program in Jakarta, Bogor, Tangerang, Depok and Bekasi)
}

\author{
${ }^{1}$ Andri Yan Prima Zani, ${ }^{2}$ Ubud Salim, Djumahir, ${ }^{3}$ Solimun \\ ${ }^{\text {I} A c a d e m y ~ o f ~ N u r s i n g ~ o f ~ R a f l e s i a, ~ D e p o k, ~ I n d o n e s i a ~}$ \\ ${ }^{2}$ Doctorate Programe Management Science of Post Graduate Scholl, Faculty of Economic and Business, \\ University Brawijaya, Malang, Indonesia \\ ${ }^{3}$ Faculty of Mathematics and Natural Sciences, University Brawijaya, Malang Indonesia
}

\begin{abstract}
Abstact: Loyal customers would provide long term benefits to the company. One of many efforts in increasing services to grow up customer loyalty was with the concept of Customer Relationship Management (CRM). This study was purposed to identify and prove: (1) could Customer Relationship Management increase students' satisfaction, (2) Could Customer Relationship Management improve the students' loyalty, (3) could Students' Satisfaction improve students' loyalty. The results of this research were hoped could enrich and complete knowledge in the field of marketing, especially the marketing strategy in the development of customer relationship management theory related to satisfaction and loyalty.

The research populations were the second level students and third level student of 5 (five) Medical Education Institutions, Nursing Study Program located in Jakarta, Bogor, Tangerang, Depok and Bekasi. The population in this research was included 683 individuals. The research samples were 219 respondents. The sampling method used was proportional random sampling area and taken in proportional way for each level. The research analysis was using Path Analysis.

The results of the research had found that: (1) CRM could increase students' satisfaction and the important factor in forming the CRM was a learning process, (2) CRM could increase the loyalty of students and lecturers' factor played an important role in determining students' satisfaction (3) students' satisfaction could improve students' Loyalty .

Keywords: Customer Relationship Management, Satisfaction, Loyalty
\end{abstract}

\section{Introduction}

The efforts for winning the competition is by changing the way of interacting with customers (Kumar, 2010), because loyal customers would give long term benefits to the company. According to Barnes (2001), $20 \%$ of loyal customers would give benefit by $80 \%$ for the company than customers who are not loyal. So the best step for the company is keeping the customer should be focused to improve the trust in them (Kotler and Fox, 1995). Customers who were not satisfied and loyal woulf give bad impact of word-of-mouth for the company (in this case was the Educational Institution) (Wang and Yang, 2010).

One of many efforts in increasing the services to grow up customers' loyalty was using the concept of Customer Relationship Management (CRM). CRM had become a key strategy to retain customers (Wang et al. 2004). CRM was a business philosophy that described a strategy of placing the customer as the center of processes and activities, also it wass key for achieving sustainable competitive advantage in the current competition.

Yuan and Chang (2001) suggested that knowledge of the customers was the key for CRM success. Without knowledge of the customers, the company could fail to meet the wishes of customers. The efforts in understanding customers and strengthen relationships with customers was very important nowadays. Satisfied customers would not only increase the loyalty but also increases good relationship with the company. CRM process in dealing with the customer through the transaction process and communication, analyze and take action based on the information to build long term relationships with customers. If CRM had been implemented properly, it would be able to improve customers' satisfaction, also increase customers' loyalty.

In some reasearches conducted in several companies, it was found that for formulating and implementing CRM was not an easy thing because of there were several constraints including the misunderstanding of CRM concept within organizations (Hoskin, 2001 in Sin et. Al., 2005). CRM was a marketing strategy in selecting and managing customers to optimize long term value. CRM was a design strategy to understand, anticipate customers' behavior, and develop stronger relationships with customers. CRM 
integrated, analyzed, disseminated information about the customer, and marketing effectiveness to provide a more professional and personal to the customers (Hoskin, 2001 in Sin et. Al., 2005).

Customers' satisfaction in the context of education was one success key for long term educational institutions. The education institutions should not think that all activities would be entirely good without considering about what was desired by the customers (in this case was students). The educational institutions should pay attention to service quality provided to the students so that the satisfaction of needs coulf be met. Satisfaction and dissatisfaction with a product or service woulf affect the pattern of subsequent behavior (Kotler, 2000).

Customer Relationship Management (CRM) research today had become a concern in the research and business practitioners. The previous studies were using Customer Relationship Management (CRM) variable that was associated with customers' satisfaction and customers' loyalty obtained various results. Jitesh et al. (2009) said that there was no relationship between the development of the CRM practice at the bank for the level of customer loyalty and CRM strategy was not profitable strategy for retail banks, particularly in India. However, other research stated that CRM was very profitable for the company and coulf achieve customer loyalty as much as possible, including Ismail et al. (2007), Chung et al. (2007), Liu (2006), Sin et al. (2005), Hsiu et al. (2011), Sarlak and Fard (2009), Zinaeldin (2005)

CRM study in the context of education was also getting various results. Some claimed that CRM could influence in reaching customers and prospective customers (students and prospective students), such as Seeman and O'Hara (2006) and Kumar (2010), but according to research of Wang and Yang (2010), stated that CRM that was using Focus Student indicator did not affect parents' satisfaction and loyalty who will enter their children to educational institutions. Kumar (2010) used indicators of information technology utilization and integrated knowledge base, and Seeman and O'Hara (2006) with indicators of student focus, student data development and management processes, while Wang and Yang (2010) measured CRM with customer focus and knowledge management. According to Dibb and Meadows (2004) and Zinaeldin (2005) said that the measurement of CRM strategy should at least have some elements including people, process, quality and customer focus.

The main purpose of the CRM application was to improve customer satisfaction. Customer satisfaction could be achieved by improving the service quality. Sarlak and Fard (2009) stated that there was a positive relationship between the CRM with service quality indicators, services acces and properties service to customer satisfaction. Other researches related to the effects of service quality on customer satisfaction and customer loyalty were conducted by Ravichandran et al. (2010), Nagata et al. (2004) and Kumar (2010). Different results were obtained by Bastos and Gallego (1997) that the service quality did not affect the customer's satisfaction and loyalty in urban dispensaries, but the opposite results were happened in rural dispensaries.

CRM was an extension of the traditional marketing mix with further improvement of customer relationships. The relationships improvement was done by giving added value of the traditional marketing mix, such as Product, Process, People and Perform better and optimized, with the added element of Rentention, Relationship, Referrals and Recovery so that there would be long-term relationships with customers (Barnes, 2001). CRM was a combination of the marketing process by using information technology in order to approach and understand the customers (Tiwana, 2001). Nykamp (2001) stated that CRM was used to generate the optimal value for the customers through communication with them, how to market the product through traditional marketing media, including product, price, promotion and distribution, as well as performing the service through an intensive relationship with the customer.

In this research, CRM used focus indicators on the customer (in this case was students) drawn from Wang and Yang research (2010) and Seeman and O'Hara (2006), Human Factors (Lecturers) and the process was taken from the traditional marketing mix theory (Barnes, 2001, and Nykamp, 2001) and Zinealdin (2005), as well as the quality of the research service referred to Sarlak and Fard (2009) with some modifications that were associated with educational institutions, especially Medical educational institutions Nursing Study Program.

\section{Customer Relationship Management}

\section{Literature Review}

CRM was a process to obtain, retain, and develop profitable customers and it required a clear focus on service attributes that could generate value to the customers so that would produce a loyalty (Brown, 2000).

Storbacka et el. (1994) defined CRM as a cooperative relationship between the provider with the customers so that both parties would be benefitted equally which could increase their value. Almost the same thing was expressed by Parvatiyar and Sheth (2001) that CRM was an integrated strategy and process of acquiring, maintaining and making friends with selective customers to create superior value for the company and customers. Nykamp (2001) stated that CRM was a focus in generating optimal value for the customers by way of company communications with customers, marketing, and serve customers through the media of product, 
price, promotion and distribution. Greenberg (2002) explained that CRM as a business strategy to create and maintain customer relationships for the long term and profitable

Temporal and Trot, 2001, argued that CRM was all done for Establishing a strong brand. Because of that, it was needed for the unity of people vision (employees), systems and organization processes to understand the consumer individually, and their wants in every interaction.

\section{Customer Satisfaction}

Customer satisfaction was the level in which the needs, wants and expectations of customers were met that would result in repeating of purchases or ongoing loyalty (Band, 1991).

Service product quality had an important role to establish customer satisfaction (Kotler and Armstrong, 1996). The more quality of products and services delivered, the customer would have higher satisfaction. When customers had higher satisfaction, it could lead to profits for the company. Satisfied customers would continue to make repeat purchases. It would be vice versa if there is unsatisfactory; it would make customers move to another product. The level of satisfaction was a function of the difference between perceived performances to expectations (Kotler, 1997).

Engel et al., (1990) defined customer satisfaction as after-purchase evaluation where the alternatives being selected at least would be equal or exceed customer expectations. Overall customer satisfaction had three antecedents; those were the perceived quality, perceived value and customer expectations. Perceived quality had a direct positive effect on customer satisfaction and overall would negatively impact on customer complaints and a positive effect on customer loyalty (Formel, et al., 1996).

\section{Customer Loyalty}

Customer loyalty was the urge to make a purchase behavior repeatedly and to build customer loyalty to a product / service that the company provided. That effort took a long time through a process of repeated purchases (Olson and Peter, 1993).

Griffin (1995), argued that the faithful or loyal customer would show regular purchasing behavior or there was a condition which required customers to purchase at least two times within a certain time interval. Loyal customers would make a purchase on a regular basis; also had a protective effect against the negative news of the products, even the loyal customers could also recommend the products to others.

Jones and Sasser (1995) argued that customer loyalty was an endogenous variable that was caused by a combination of satisfaction, so that customer loyalty was a function of satisfaction. If the relationship between customer satisfaction and loyalty was positive, then the high satisfaction would increase customer loyalty.

Customer loyalty in the context of marketing services was defined as response closely related to pledge or promise to uphold the commitments that underlied the continous relation, and usually being reflected in the ongoing purchase of the same service provider on the basis of dedication and pragmatic constraints (Tjiptono, 2002). Customer loyalty could be defined as a customer's commitment for a brand, based on the very positive attitude and was reflected in the consistent use (Sheth, et al., 1999 in Tjiptono, 2000). The definition included two important components; those were loyalty behavior and loyalty as an attitude

\section{Method}

This study used a quantitative approach to conduct survey research; the sample was taken from the population by using questionnaires as a data collection tool. The location of research was carried out in five Medical Education Institutions Nursing Study Program located in Jakarta, Bogor, Depok, Tangerang and Bekasi (Jabodetabek).

The population in this research were all students of Medical Education Institutions Nursing Study Program in second level (semester III and IV) and third level (semester V and VI) in five educational institutions in Jakarta, Bogor, Depok, Tangerang and Bekasi, for 683 individuals.

The sampling technique used in this research was random proportional sampling, where samples were taken according to the proportion of the number of students from each educational institution. The number of samples is at least 252 students. Sampling technique was done by simple random sampling. After distributing the questionnaire to the respondents, from the total of 252 respondents, only 219 questionnaires from the decent responents could be processed further.

The analytical tool used in this research was a quantitative analysis, with path analysis.

Research hypothesis :

H1: the Increasing of Customer Relationship Management (CRM) would be able to increase student satisfaction (SS).

H2: The increasing of Customer Relationship Management (CRM) would be able to increase student loyalty (SL). 
H3: The Increasing of Student Satisfaction (SS) would be able to increase student loyalty (SL).

\section{Results}

The descriptive analysis was resulted respondent characteristics respondents as follows:

Table 1. The description of Respondent characteristics

\begin{tabular}{|c|c|c|c|}
\hline No & Descriptive & Total & $(\%)$ \\
\hline \multicolumn{4}{|c|}{ Respondents Gender } \\
\hline 1 & Female & 121 & 62,45 \\
\hline 2 & Male & 88 & 37,55 \\
\hline \multicolumn{4}{|c|}{ Respondents Age } \\
\hline 1 & $<20$ years age & 120 & 62,46 \\
\hline 2 & $>20$ up to 23 years age & 89 & 37,54 \\
\hline Tot & & 219 & 100 \\
\hline
\end{tabular}

The number of respondents' learners of Healt Education Institutions Nursing Study Program in Jabodetabek, the male number was less than women. From 219 respondents, there was $62.45 \%$ of female and $37.55 \%$ of male.

The age composition of students in Medical Education Institutions Nursing Study Program was under the age of 20 years $(62.46 \%)$ and the rest were more than 20 years $(37.54 \%)$.

Table 2. The Profile of Research Variable

\begin{tabular}{|l|l|l|}
\hline Variable/Indicators & Means & $\begin{array}{l}\text { Loading } \\
\text { Factors }\end{array}$ \\
\hline CRM \\
- Focuse of students & 3.790 & 0.799 \\
- Lecturers & & \\
- Process & 3.660 & 0.814 \\
- Service Quality & 3.830 & 0.870 \\
\hline Means Variabel CRM & 3.830 & 0.787 \\
\hline Students Satisfaction(SS) & 3.780 & \\
- Information & 3.620 & 0.803 \\
- Tution fee & 3.860 & 0.634 \\
- MA Graduation & 3.710 & 0.719 \\
- Lecturer & 3.680 & 0.814 \\
\hline Means variable (SS) & 3.72 & \\
\hline Students Loyalty (SL) & & \\
- Attitude & 3.710 & 0.873 \\
- Behaviour & 3.750 & 0.873 \\
\hline Means variable SL & 3.73 & \\
\hline
\end{tabular}

The greatest contribution in shaping the CRM variables were the process factors (3.830 average and 0.870 loading factor) and the most minor contribution in shaping the CRM variables were Quality factors Service (3.830 means and 0.787 loading factor). CRM factors had not been well perceived by students were lecturers factor (3.660average).

The greatest contribution in shaping SS variables were factors of teachers (3.680average and 0.814 loading factor), and the most small contribution in shaping the SS variables was a factor of tuition fees variable (3.860 means and 0.634 loading factor). Most students were not satisfied with the information applicationin Medical Education Institutions (3.620average) followed by lecturers factor (3.680average). These results were directly proportional to the result of the above CRM factors, where the bad service and the lecturer ability lead to the student dissatisfaction.

The greatest contribution in shaping the SL variable was attitude factor and behavior (average of 3.710 and 3.750 with a loading factor of 0.873 ). Students had not shown yet a good loyal attitude towards Medical Education Institutions (3.710 averages).

\section{Hypothesis Testing Results}

Size fit the model to the path analysis was the total determiantion coefficient $\left(\mathrm{R}_{\mathrm{m}}^{2}\right)$, calculated based on $\mathrm{R}^{2}$ for the dependent variable $\mathrm{SS}=0.487$ and $\mathrm{R}^{2}$ for the dependent variable $\mathrm{SL}=0.285$ $R_{m}^{2}=1-(1-0.487)(1-0.285)=0.6332$ 
This suggested that the contribution of CRM and SS to SL (based on the analysis result model) was equal to $63.32 \%$.

From the result of Path analysis, it was found a significant effect between the independent variable (X) and the dependent variable (Y). The results of hypothesis testing were completed can be seen in Table 3 as follows:

Table 3. Hypothesis Testing Result

\begin{tabular}{|l|l|l|l|l|}
\hline$X$ & $Y$ & $\begin{array}{l}\text { Path } \\
\text { Coef. }\end{array}$ & P-value & Decs. \\
\hline CRM & SS & 0.691 & $<0.001$ & Sig. \\
\hline CRM & SL & 0.339 & $<0.001$ & Sig. \\
\hline SS & SL & 0.241 & 0.003 & Sig. \\
\hline
\end{tabular}

The analysis results of CRM variable with SS showed coefficient result of 0.691 with a significance level of $<0.001$, which meant that there was a significant effect of CRM on SS. Obtaining the results of this analysis indicated that the better CRM would enhance SS (hypothesis 1 was fulfilled).

The results of the analysis for second hypothesis also showed a significant ( $p$ value $<0.001$ ), meant that there was a significant effect of CRM on SL. The Obtaining of the analysis results indicated that the better CRM would enhance SL.

The result analysis also obtained a coefficient gain of 0.241 with a significance level of 0.003 for the relationship between SS and SL; it meant that there was a significant effect of SS to SL. The Obtaining of the results of this analysis indicated that the increasing SS would increase SL.

\section{The Effect of CRM on Student Satisfaction (SS)}

\section{Discussion}

The analysis results of the CRM influence on SS indicated coefficient value that was positive and significant. The Obtaining of this result implied that there was a direct relationship between CRM and SS. Educational Institutions Students felt that the existing CRM encouraged the SS. The results of student responses to CRM were perceptioned for the better. Students felt that the existing CRM tend to be more stressed on the institutions to develop good relationships with the students. Beside that, it provided adequate facilities to the needs of the student.

The results of this research supported the results of research conducted by Seeman and O'Hara (2006), and Kumar (2010), which suggested a significant influence of CRM on SS. These results were contrasted with the results obtained by Wang and Yang (2010), which stated that there was no influence between CRM and SS on Customer Focus indicator. This difference was obtained in which the research of Wang and Yang (2010) stated that CRM with Customer Focus indicator has no significant effect on Satisfaction and Loyalty, but CRM with Knowledge Management indicators had significant effect on customer satisfaction and loyalty. While in this research, CRM with Student Focus indicators, Human Factors, Process and quality of service factors significantly influenced student satisfaction and loyalty. The difference in results obtained because of the research by Wang and Yang (2010), the respondents were student's parents who put their children in school, whereas in this research, the respondents were students in level II and level III who felt themselves the CRM implementation in their institution. The results of this research enriched the research of CRM, where CRM as the development of the mixed theory of traditional marketing consisting of some elements, such as product, people, promotion, and place, enriched with additional elements of customer focus and quality of service. In the new paradigm in strategic marketing that foster long-term relationships with customers (customer to business) through customer relationship management (CRM) should put consumers as subjects, not as objects as in the old paradigm, for it must be focused on service improvement and increased customer interest to service quality. The results of this study enriched CRM functionality to improve customer satisfaction that made them loyal to organizations including educational institutions. The implementation of CRM in educational institutions could engage students as subjects, as in the application of Tri Dharma University, which was to involve students in academic achievement as a teaching assistant (aspects of the development of science), social committees in devotional activities, compensation (aspects of community service), and members in faculty research activities (aspects of scientific research).

\section{The influence of CRM to Student Loyalty (SL)}

The analysis result of the CRM influence on SL indicated coefficient that was positive and significant. The obtaining of this result implied that there was a direct relationship between CRM and SL and their significant influence. Students felt that the existing CRM had been in accordance with existing conditions so that it had a direct impact on SL. The research results was different with the results of research conducted by 
Wang and Yang (2010), Jitesh and Vijay (2009) and Bastos (2008) which showed that there is no direct relationship between CRM and SL, but in this research, there was a significant relationship between CRM and SL .

\section{The Effect of Student Satisfaction (SS) to the Student Loyalty (SL)}

The analysis result of the SS influence on SL indicated positive coefficient value and significant. The Obtaining of this result implied that there was a direct relationship between SL and SS and their significant influence. Students feel that the SS that have so far had a great influence and direct to SL.

The results of this study supported the research conducted by Seeman and O'Hara (2006), Kumar (2009) and Wang (2010) which stated SS positively and significantly related to SL. SS Positive relationship to SL meant that good SS would have an impact on the increasing of SL. These results reinforced the previous theory, that a satisfied customer would be loyal to the organization and act. These things were different for an educational institution, because the level of the relationship between institutional and customer existed fro long enough (during the education), when students were satisfied, then they could improve the quality of the institution's achievements both academic and non-academic, and could help to provide input - input and relief assistance (from senior to junior students) in terms of learning (teaching assistant), so an understanding of the subject could be mastered with a more equitable for all students. The satisfied students would felt close to the institution would be more resistant to the negative issues, more enthusiasm in learning, more proud of alma mater, and it would be a very powerful media campaign to find and recruit new students without the use of promotional media (newspapers, banners etc. ).

The findings in this research that the critical factor in the CRM implementation in Medical Education Institutions Nursing Study Program was process factors and lecturer factor, but in reality both of these factors had not been implemented by the Institute of Education well, thereby would reduce SS, it also affected the low SL to the Institution education.

\section{Conclusions}

CRM could improve student satisfaction. This indicated that satisfaction had been established through existing programs on CRM. Empirical results showed that the students were not satisfied with the CRM program implemented primarily institutional factors related to faculty and the learning process. Strong student satisfaction could assist organizations to survive in the long term.

CRM could improve student loyalty, so that a good CRM program and integrated CRM could increase the love of students to their alma mater. Empirical results showed students in medical education institutions Nursing study program had not been satisfied with CRM program that established from institutions so that they had a good attitude and behaved well to promote to the public.

Student satisfaction could improve student loyalty. Empirical results found that student satisfaction of Medical education institutions Nursing Study Program had not been good, especially lecturers factors and information systems.

\section{Reference}

[1] Band, WA, 1991. Creating customer value: Designing and implementation a total corporate strategy. Canada: John Wiley and Sons, Inc.

[2] Barnes, James G. , 2001. Secrets of Customer Relationship Management (translation), McGraw-Hill, Publisher Andi Yogyakarta.

[3] Bastos, Jose Augusto rosa and Gallego, Pablo de Munoz. 1997. Pharmacies Customer Satisfaction and Loyalty - A Framework Analysis ", Documento de Trabajo 01/08.

[4] Brown, Stanley W. , 2000. Customer Relationship Management. Singapore: John Wiley and Sons Canada, Ltd.CRM - Wikipedia ( http://en.wikipedia.org/). September 2011.

[5] Chung et al., 2007. An empirical study of customer relationship management implementation in Taiwan's Machine Industry, Business and Public Affairs, Vol. 1, Issue 1. P.1-12

[6] Chitra Nair. 2009, A Case Study of CRM Adoption in Higher Education. DePaul University chool of Computer Science Chicago, IL cnair1@depaul.edu,

[7] Dibb and Meadows. , 2004. Relationship marketing and CRM: a financial service case study, Journal of Marketing Strategy, Vol. 12 p. $11-125$

[8] Dimitriades, ZS. , 2006. Customer Satisfaction, Loyalty and Commitment in Service Oganizations: Some Evidence from Greece, Management Research News, vol. 29 (12), 2006, pp.782-800.

[9] Dyche, J., 2002. The CRM Handbook, Addison-Wesley, 2nd printing, March 2002

[10] Engel, J., R. Blackwell, Miniard, P. , 1990. Consumer Behaviour, $6^{\text {th }}$ ed. Sydney: Harcourt, Brace Jovanovich Publishers

[11] Franka. , 2009. A Successful CRM Implementation Project in a Service Company: Case Study, Organizacija, Volume 42 Number 5.

[12] Fornell, C., Johnson, M., Anderson, EW, Cha, J. \& Everitt Bryant, B., 1996. The American customer satisfaction index: nature, purpose, and findings, Journal of Marketing, 60 (October), pp. 7-18.

[13] Griffin, Jill. , 1995. Customer Loyalty: How to earn it, How to keep it, USA: A Division Of Simon and Schukers Inc..

[14] Greenberg, Paul. , 2002. CRM at the speed of Light: Capturing and Keeping Customers in Internet Real Time. 2nd Edition. California: McGraw-Hill Book Co.. 
[15] Hsiu-Yuan H, Ching-Chan C, Shao-I C and Fu-Yuan H, 2011. A study of customer satisfaction, customer loyalty and quality attributes in Taiwan's medical service industry, African Journal of Business Management, Vol. 5 (1), pp. 187-195, 4 January

[16] Ismail et al. , 2007. Technology dimension of CRM: the orientation level and ist impact on the business performance of SMEs in Malaysia, International Journal of Electronic Customer Relationship Management, Vol. No. 1. 1 p. 16-28

[17] Jayachandran, S. et al., 2010. The Role of Relational Information Processes and Technology Use in Customer Relationship Management, Journal of Marketing, vol. 69, pp. 177-192

[18] Jill Dyche. , 2002. The CRM Handbook. Addison-Wesley, USA

[19] Jitesh, P., K. Vijay, and Kallol D, 2009. Customer Relationship Management (CRM) Best Practices and Customer Loyalty A Study of Indian Retail Banking Sector, European Journal of Social Sciences - Volume 11, Number 1

[20] Jones TO and Sasser WE, 1995. Why Satisfied Customers Defect, Harvard Business Review, November-December, 88-99

[21] Kalakota, R and Robinson, M. , 2000. Roadmap to Success, Reading, Massachusetts: Addison-Wesley.

[22] Kotler, Philip and Gary Armstrong, 1996, Principles of Marketing, Seventh Edition, International Editrion, Prentice Hall, Inc.., Englewood Cliffs, New Jersey.

And Fox, K. , 1995. Strategic Marketing for Educational Institutions. Englewood Cliffs, NJ: Prentice Hall, 1995. 2000. Marketing Management, The Millennium Edition, New Jersey: Prentice Hall International, Inc.. Enterprise of Enterprise information systems, Volume-2 Issue-2.

[26] Lin, HH., And Wang, YS. , 2006. An examination of the determinants of customer loyalty in mobile commerce contexts. Information \& Management, 43, 271-282.

[27] Liu, AH 2006. Customer value and switching costs in business services: developing exit barriers through strategic value management, Journal of Business \& Industry Marketing, Vol. No. 21. 1 p. 30-37

[28] Mithas, Sunil, MS Krishnan, and Claes Fornell, 2002. Effect of Information Technology Investments on Customer Satisfaction: An empirical Analysis, working paper, Ross School of Business, University of Michigan.

[29] Nagata, H., Sato, Y., Gerrard, S. \& Kytömäki, P. , 2004. The dimensions that construct the evaluation of service quality in academic libraries. Performance Measurement and Metrics, 5 (2), 53-65.

[30] Nykamp, Melinda. , 2001. The Customer Differential: The Complete Guide to Implementing Customer Relationship Management, AMACOM, New York.

[31] Olson, JC and Peter, JPP, 1993. Consumer Behavior and Marketing Strategy, Homewood IL: Irwin.

[32] Parvatiyar, Atul and Jagdish N. Sheth. , 2001. Customer Relationship Management: Emerging Practice, Process, and Discipline, Journal of Economic and Social Research 3 (2) 2001, 2002 Preliminary Issue, 1-34

[33] Rangkuti, Freddy, 2002. Measuring Customer Satisfaction, PT. Scholastic Press, Jakarta

[34] Ravichandran, K., Bhargavi K., and Arun Kumar S., 2010. Influence of Service Quality on Banking Customer's Behavioural Intentions, International Journal of Economics and Finance, Vol. 2, No. 4.

[35] Sarlak, M. Ali and Fard, RS , 2009. The Impact of CRM on the Customer Satisfaction in Agricultural Bank, American Journal of Economics and Business Administration , 1 (2): 173-178,

[36] Seeman, Elaine D. and O'Hara, Margaret. , 2006. Customer Relathionship Management in Higher Education : using information system to improve the student-school relationship, Campus-Wide Information Systems, Vol.23, No. 1, 2006

[37] Sin, Leo YM, Alan CB Tse., and., Frederick HK Yim, 2005. CRM: conceptualization and scale development, European Journal of Marketing, Vol. 39, No. 12, p. 1264-1290

[38] Storbacka, K., Strandvik, T., \& Grönroos, C. 1994. Managing customer relationships for profit: The dynamics of relationship quality, International Journal of Service Industry Management , 5 (5), 21-38.

[39] Temporal, Paul and Martin, Trot. 2001. Romancing the Customer, Maximing Brand Value through Powerful Relationship Management, John Wiley \& Sons (Asia) Pte Ltd, Singapore

[40] Tiwana, Amrit. 2001. The Essentials Guide to Knowledge Management : E-Business and CRM Aplications, Prentice-Hall, USA

[41] 41) Tjiptono, Fandy. 2000. Strategi Pemasaran. Yogyakarta. Penerbit Andi offset, Yogyakarta

[42] 42) 2002. Prinsip-prinsip Total Quality Service. Yogyakarta. Publisher Andi

[43] 43) Osarenkhoe dan Bannani. , 2007. An exploratory study of implementation of customer relationship management strategy, Business Process Management Journal, Vol. 13 No. 1 p. 139-146

[44] O'Brien, James A. 2002. Customer Relationship Management. McGraw - Hill.

[45] Wang, Y., HP Lo, R. Chi and Y. Yang. , 2004. An Integrated Framework for Customer Value and Customer-Relationship Management Performance: A Customer-based Perspective from China, Managing Service Quality, vol. 14(2/3), pp. 169-182.

[46] Wang, Mei Ling and Yang, Fei-Fan. , 2010. How does CRM create better customer outcomes for small educational institutions? African Journal of Business Management. Vol. 4(16), pp. 3541-3549.

[47] Yuan, ST, \& Chang, WL, 2001. Mixed-Initiative Synthesized Learning Approach For Web-Based CRM. Expert Systems with Applications , 20, 187-200

[48] Zeithaml, VA, Berry, L., \& Parasuraman, A. 1993. The nature and determinants of customer expectations of service. Journal of the Academy of Marketing Science, 21 (1), 1-11.

[49] Zineldin, Mosad. 2005. Quality and customer relationships management (CRM) as competitive strategy in the Swedish banking industry. The TQM Magazine, Vol. 17 No. 4 p. 329-344 .2006. The royalty of loyalty: CRM, Quality and retention . Journal of Customer Marketing, Vol.23, No. 7 p.430-437 